\title{
Two New Miospores Species from Triassic-Jurassic Boundary in Borehole Tel Hajar-1 South West Mosul City, Iraq
}

Amer D. Nader

Yasser H. Kddo

\author{
Department of Geology \\ College of Science \\ University of Mosul
}

(Received 26/1/2012, Accepted 7/5/2012)

\begin{abstract}
Two new species of miospores are described from Upper Triassic- Lower Jurassic Butmah Formation in borehole Tel-Hajar-1- northern Iraq. These are Concavisporites baăjensis sp.nov. and Concavisporites mosulensis sp. nov.

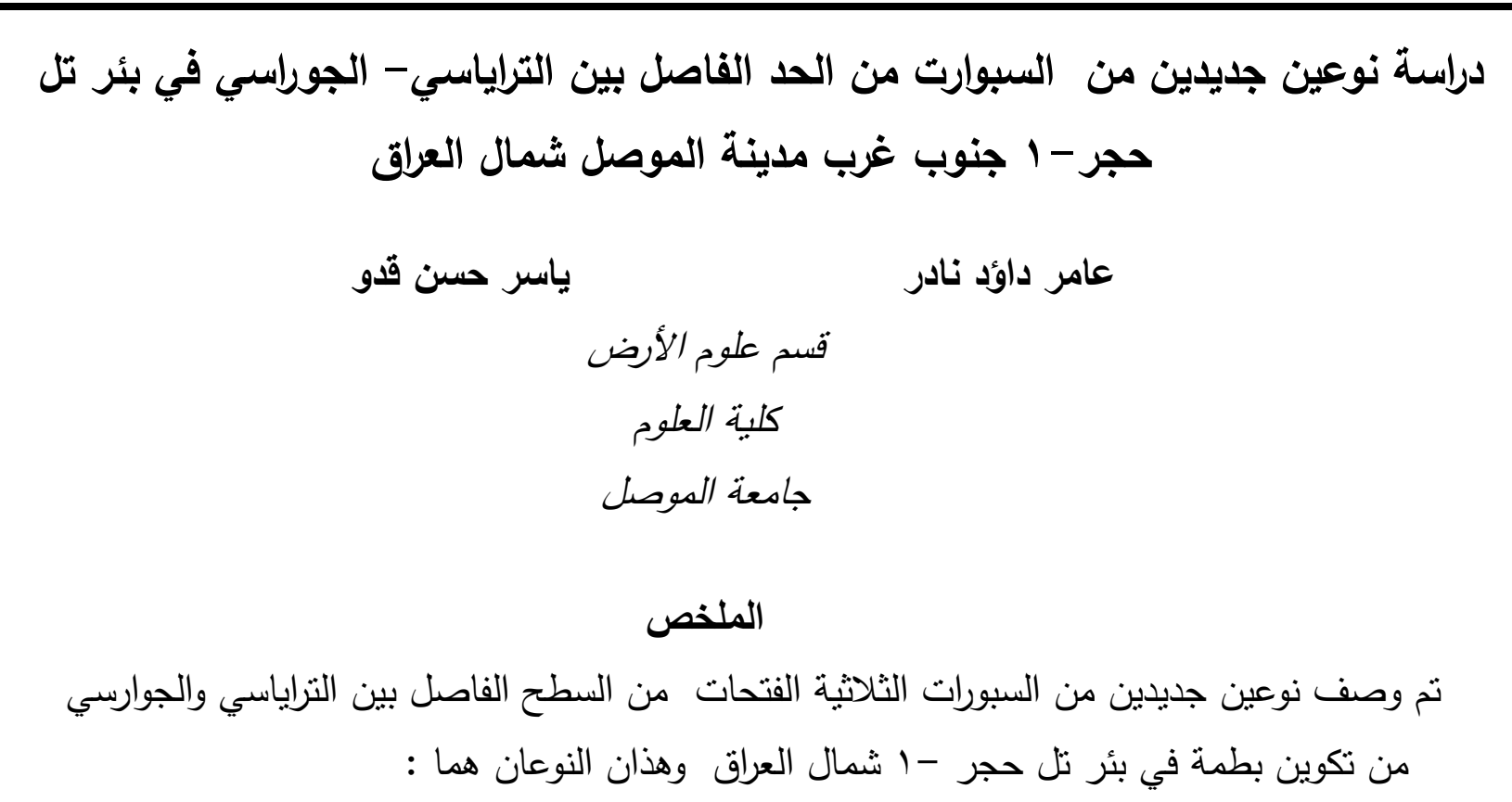

Concavisporites baăjensis sp. nov. and Concavisporites mosulensis sp. nov.

\section{INTRODUCTION}

During the course of detailed palynological studies of Triassic and Jurassic strata

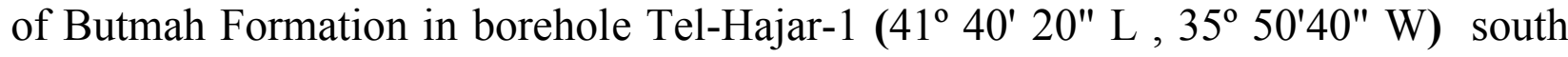
west Mosul city, Iraq. Two morphologically distinctive species of dispersed trilete spores have been encountered.Tel-Hajar-1 well was drilled on the Tel-Hajar structure which is located $30 \mathrm{Km}$. southwest of Sinjar town (Fig.1). The purpose of this paper 
is to document these species systematically and to relate their occurrence to the palynostratigraphic sequences.

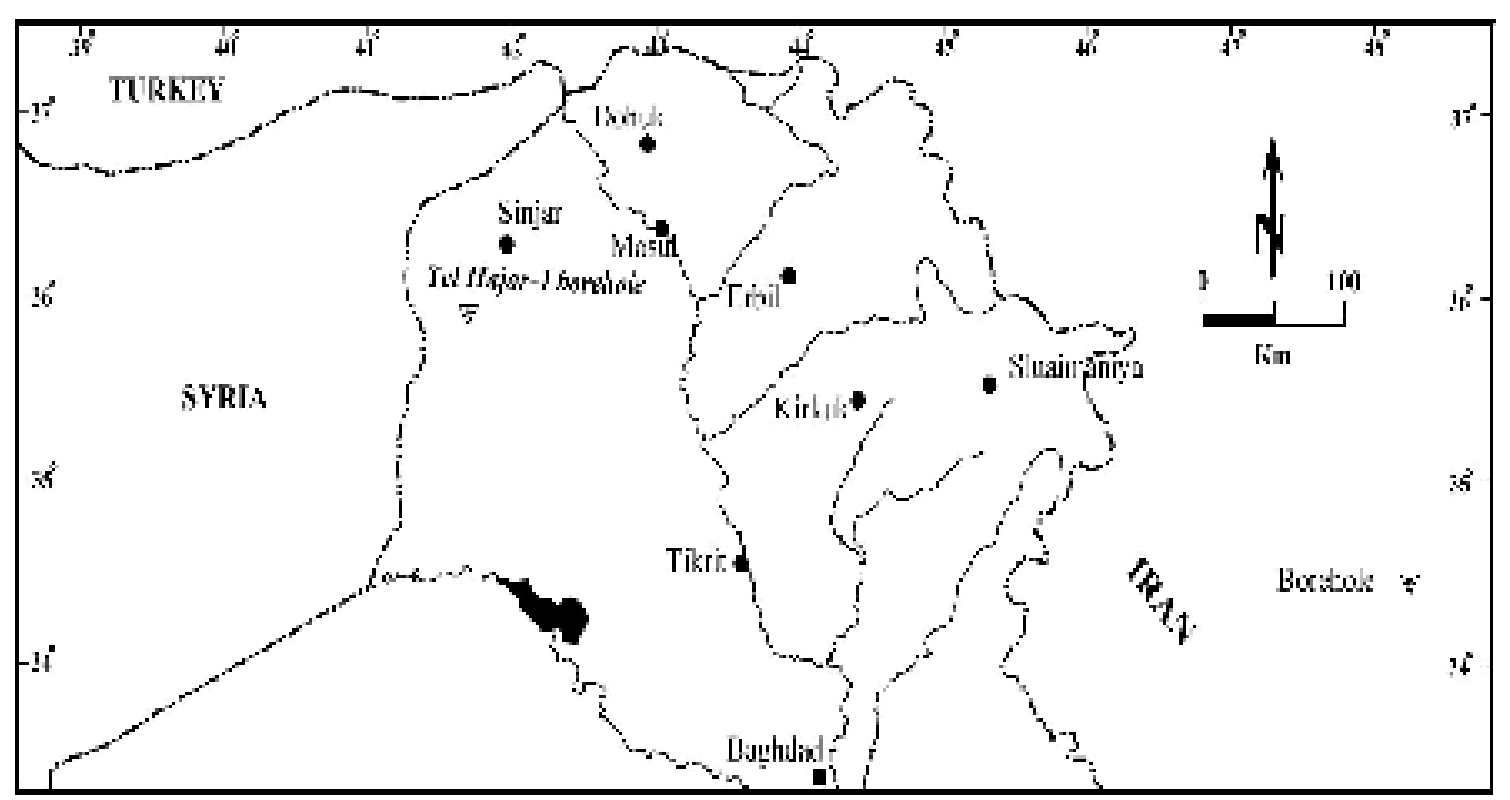

(Fig. 1): Location map of borehole Tel Hajar-1

\section{STRATIGRAPHY}

The studied samples represent part of Butmah Formation which is penetrated in borehole Tel-Hajar-1. The Butmah Formation was first described by (Dunnington 1953 in Bellen et al., 1959) from borehole Butmah -2 south west Mosul city (Since Butmah Formation is not recognized in surface exposures). The formation is a heterogeneous aggregate of sediment of calcareous - argillaceous and evaporitic rock suites (Fig. 2).

According to (Jassium and Goff, 2006) the upper (200m.) of the Butmah Formation in the type section consist of oolitic and detrital limestone with beds of argillaceous limestone, shale and anhydrites. The middle part $(180 \mathrm{~m}$.) is oolitic, argillaceous and dolomitic with sandstone and shale bed. The lower part $(120 \mathrm{~m}$.) is composed of limestone with bedded anhydrite.The lithofacies and faunal assemblages indicate that Butmah Formation was deposited in shallow water lagoonal and sabkha environment. 


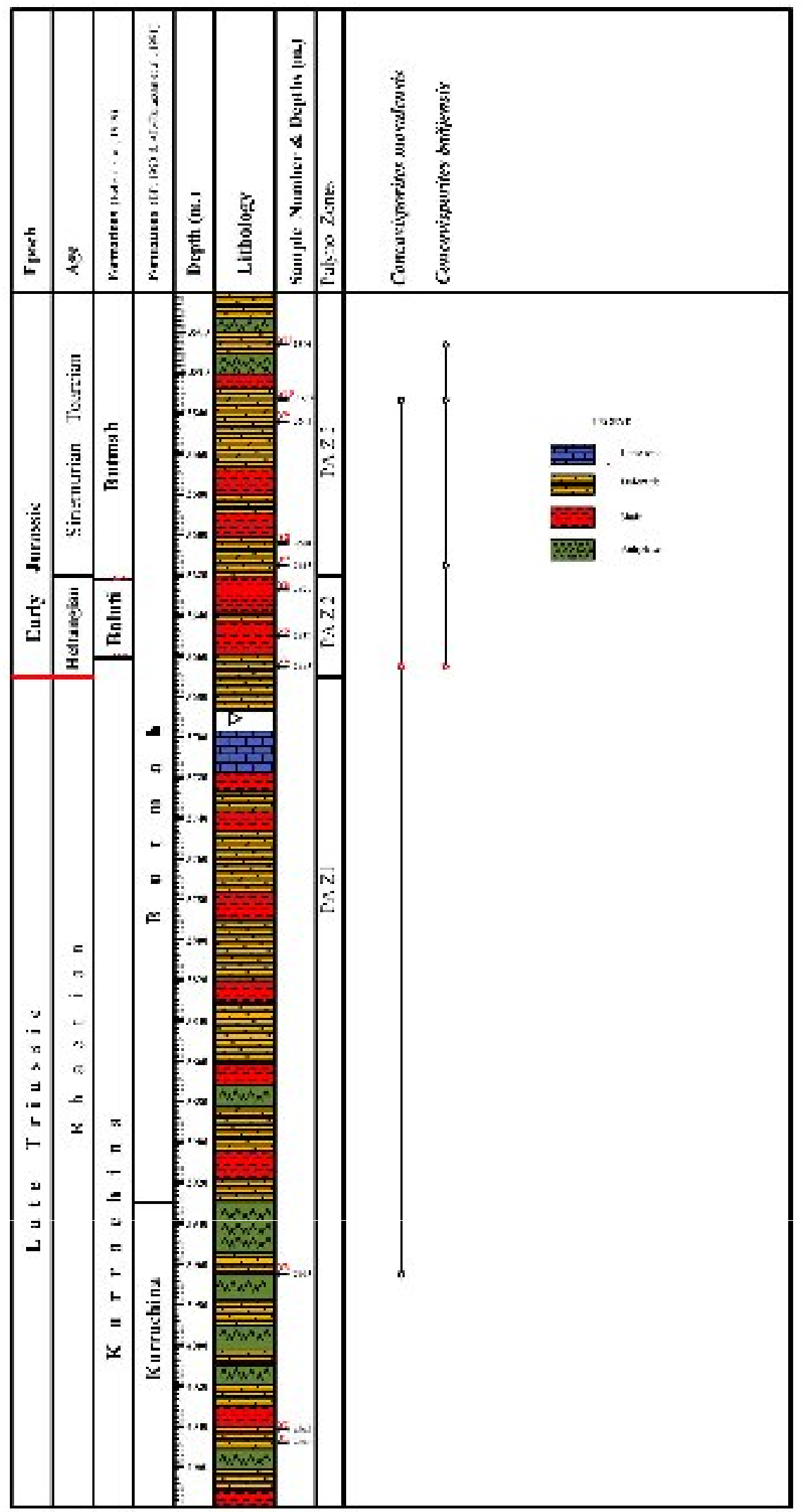

Fig. 2: Stratigraphic Succession, Sample Position and Range of the New Species in Borehole Tel-Hajar-1 (Kddo, 2011). 


\section{SYSTEMATIC PALAEONTOLOGY}

Anteturma: PROXIMEGERMINANTES Potoniè, 1970.

Turma: TRILETES Reinsch emend. Dettmann, 1963.

Suprasubturma: ACAVATITRILETES Dettmann, 1963.

Subturma: AZONOTRILETES Luber emend. Dettmann, 1963.

Infraturma: LAEVIGATI Bennie and Kidston emend. Potoniè, 1956.

Genus: Concavisporites Pflug in Thomson and Pflug 1953, emend. Delcourt and Sprumont, 1955.

Type Species: Concavisporites rugulatus Thomson and Pflug 1953, Pl.1, Fig.19.

Concavisporites baăjensis sp. nov.

Pl. 1, Figs.1-4

2009 Concavisporites sp. Götz et al , P.407, Pl. I, Fig. g.

2011 Concavisporites sp.1. in Kddo, P. 23 , Pl.3, Figs. 6,7.8 and Pl. 4, Fig.1.

Diagnosis: Miospores radial, Trilete. Amb triangular, sides concave, angles broadly rounded. Laesurae distinct, simple, straight, often accompanied by narrow lips $(1 \mu \mathrm{m}$.) or less in width sometimes opened, 3/4 - 4/5 of spore radius in length. Tori distinct (3-5 $\mu \mathrm{m}$.) wide, fading towards the apices. A distinct ribbon-like folds around the amb developed. These bulbous folds when concide with amb the margin became undulat. Exine acavate, laevigate, often show minor convolute folds on the proximal and distal surface.

Size: $42(47.5) 53 \mu \mathrm{m}$.

Holotype: Borehole/Tel Hjar-1 /Sample No. (Y4)/ Depths 3665(2)/ R.110.8, 2.2.

Name derivation: After baãj county in Mosul Governerate.

Comparison: Concavisporites sp. figured by (Götz et al., 2009) Pl.1, Fig. g , but not described, from the Triassic - Jurassic boundary in Hangary look very similar to our 
new species. Concavisporites baãjensis is different from other members of the genus by the presence of convolute folds around the amb.

Stratigraphic importance: This species appears at the turnover boundary between Triassic and Jurassic boundary in Iraq and Hangary, so it is potentially index species for this age.

Natural affinity: Filicopsida.

Age range: Triassic - Jurassic boudary and Lower Jurassic.

Concavisporites mosulensis sp.nov.

Pl. 1 , Figs. $5-8$

2011 Concavisporites sp.2. in Kddo, P. 23, Pl. 4, Figs. 2, 3, 4.

Diagnosis: Miospores, radial, trilete, Amb triangular, sides straight, angles narrowly rounded, Laesurae simple, usually opened, $3 / 4-4 / 5$ of spore radius in length. Tori distinct $2-4 \mu \mathrm{m}$. wide around the laesurae in the inter radial regions, radial regions free from tori. Exine acavate, laevigate ,numerous convolute folds present on the proximal and distal surface, theses folds may connect to form psudoreticulum ornamentation, often forming a ribbon like, reflected at the margin of the spores giving the appearance of undulate margin.

Size: $36(61) 59 \mu \mathrm{m}$.

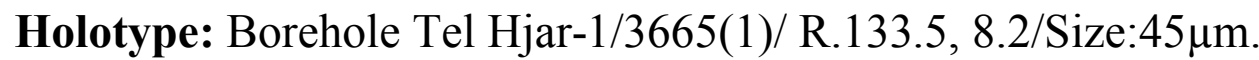

Name derivation: After Mosul city.

Comparison: This species is distiguished from Concavisporites baăjensis by its straight sides and narrow angles and the absence of the tori at the radial regions.

Stratigraphic importance: This species appears at the turnover boundary between Triassic and Jurassic boundary in Iraq and Hangary, so it is potentially index species for this age.

Natural affinity: Filicopsida.

Age range: Triassic - Jurassic boudary and Lower Jurassic. 


\section{REFERENCES}

Al-Kurassan, Ab. H., Al-Saddoni, F. and Al-Khiat, A., 1991. Stratigraphic Succession of Triassic and Jurassic Periods in Iraq. Unpublished Study, INOC, Baghdad.

Bellen, R. C., Van, Dunnington, H. V., Wetzel, R. and Morton, D., 1959. Lexique Stratigraphique International Asie, Iraq. Intern. Geol. Congr. Comm. Stratigr. 3, Fasc.10a, pp.1 - 333.

Dunnigton, H. V., 1953. Subsurface Rock Unit Nomenclature for Northern Iraq. Manuscript Report No. IDLR, INOC Library, Baghdad.

Götz, A. E., Ruckwied, K., Pálfy, J. and Haas, J., 2009. Palynological Evidence of Synchronous Changes within the Terrestrial and Marine Realm at the Triassic/Jurassic Boundary (Csővár section, Hungary). Review of Palaeobotany and Palynology, 156, pp. $401-409$.

Jassim, S. and Goff, J., 2006. Geology of Iraq. Dolin, Prague and Moravian Museum, Brno, Czech Republic, 337 p.

Kddo, Y. Hassan ., 2011. Palynostratigraphy of Late Triassic-Early Jurassic Strata in Boreholes Tel-Hajar-1 and Kand-1 Northern Iraq. Unpublished Ph.D. Thesis, Mosul University,198 p.

\section{Plate 1}

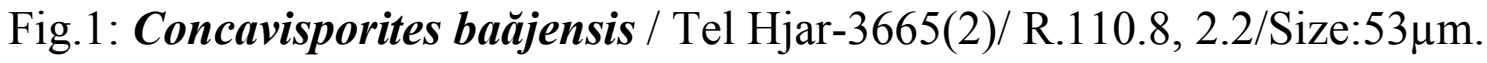

Fig.2: Concavisporites baăjensis / Tel Hjar-3665(2)/ L.109.5, 9/Size:42 $\mu \mathrm{m}$.

Fig.3: Concavisporites baăjensis / Tel Hjar-3665(1)/ R.114.6, 2.7/Size:48 $\mu \mathrm{m}$.

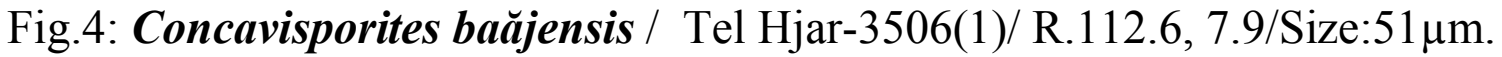

Fig.5: Concavisporites Mosulensis / Tel Hjar-3665(1)/ R.131.7, 5/Size:59 $\mu \mathrm{m}$.

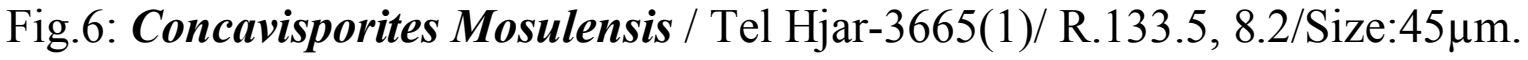

Fig.7 Concavisporites Mosulensis / Tel Hjar-3665(1)/ R.102.1, 2.2/Size:36 $\mu \mathrm{m}$.

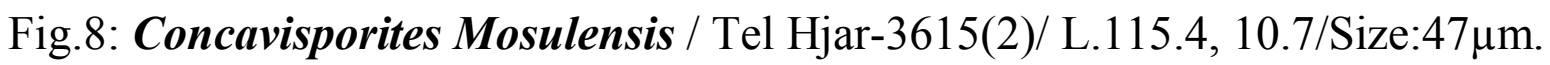




\section{Plate 1}
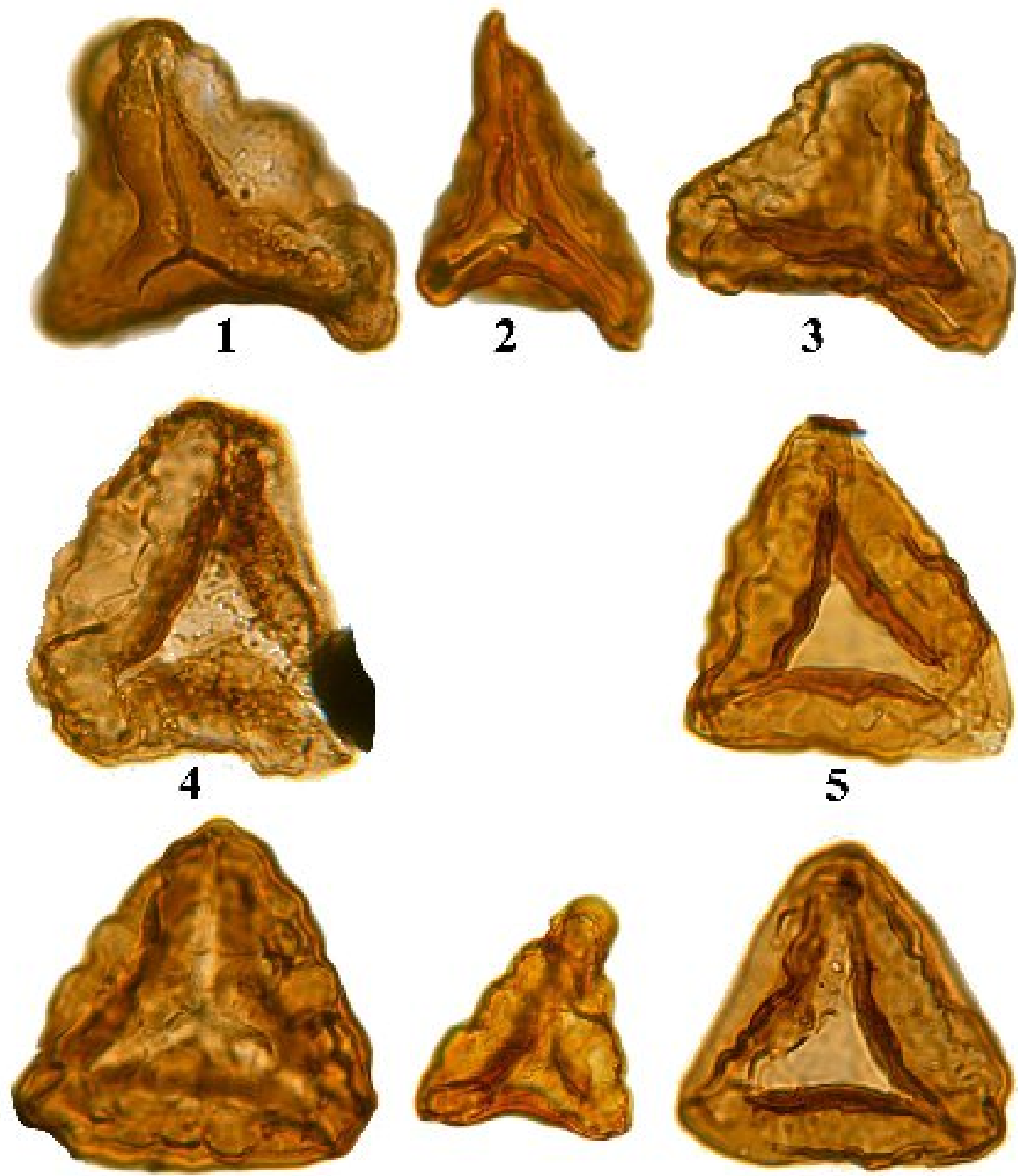

6

7

8 